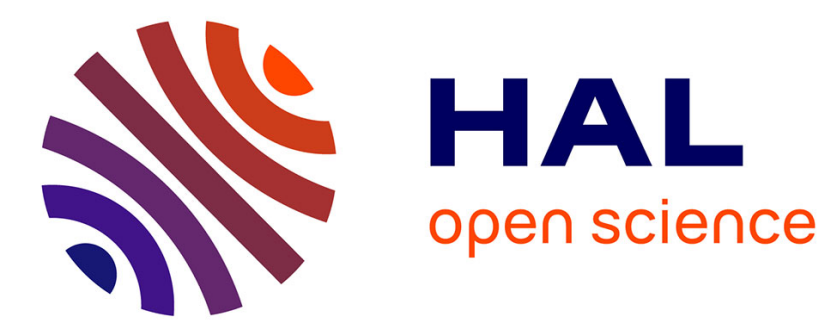

\title{
Landscapes and regional development: What are the links?
}

Jean-Christophe Dissart

\section{To cite this version:}

Jean-Christophe Dissart. Landscapes and regional development: What are the links? Cahiers d'Economie et de Sociologie Rurales, 2007, 84-85, pp.61-91. hal-01201159

\section{HAL Id: hal-01201159 \\ https://hal.science/hal-01201159}

Submitted on 17 Sep 2015

HAL is a multi-disciplinary open access archive for the deposit and dissemination of scientific research documents, whether they are published or not. The documents may come from teaching and research institutions in France or abroad, or from public or private research centers.
L'archive ouverte pluridisciplinaire HAL, est destinée au dépôt et à la diffusion de documents scientifiques de niveau recherche, publiés ou non, émanant des établissements d'enseignement et de recherche français ou étrangers, des laboratoires publics ou privés. 


\section{Landscapes and regional development: What are the links?}

Jean-Christophe DISSART 


\section{Jean-Christophe DISSART *}

\section{Paysages et développement régional : quels sont les liens?}

Résumé - En dépit d'un intérêt croissant pour les paysages ruraux, des avancées dans les technologies de l'information et des améliorations dans les transports, nombre de zones rurales restent en décalage socio-économique par rapport aux zones urbaines. Les espaces ruraux qui connaissent une croissance significative sont situés à proximité des agglomérations ou offrent des aménités remarquables qui attirent population et entreprises. Les paysages, comme les aménités, sont définis comme des caractéristiques locales spécifiques qui accroissent l'attractivité d'une région donnée. Les liens entre aménités et croissance régionale ont été mis en évidence par divers types de démarches empiriques. Toutefois, l'articulation entre offre et demande d'aménités et les conséquences de leur présence sur le développement méritent d'être clarifiées. Cet article de synthèse aborde plusieurs enjeux. Tout d'abord, aménités et paysages (ainsi que leurs caractéristiques) sont définis et décrits, en particulier en tant que biens économiques. Ensuite, sont présentés les facteurs d'offre et de demande. Puis les liens entre aménités, paysages et développement régional sont explicités, à la fois en termes de mécanismes d'impact et d'arrangements institutionnels. Enfin, nous soulignons des enjeux-clés de politique publique et de recherche future.

Mots-clés : paysage, aménité, zone rurale, développement régional, développement économique

\section{Landscapes and regional development: What are the links?}

Summary - Despite increasing interest for rural landscapes, information technology advances, and transportation improvements, rural areas generally continue to lag bebind urban ones with respect to many socioeconomic indicators. Those rural areas that experience significant growth, bowever, are either located close to metropolitan areas or offer outstanding amenities that attract population and firms. Landscapes, as amenities, are defined as location-specific features that enbance the attractiveness of a given location. The empirical connection between amenities and regional growth has been established, but supply and demand issues of amenities and how their presence might lead to increased development still need clarification. This survey paper deals with several issues. First, amenities and landscapes and their characteristics are defined and described, particularly as economic goods. Second, supply and demand factors for amenities are presented. Third, the links between amenities, landscapes and regional development are explained, via both impact mechanisms and institutional arrangements. Last, key public policy and further research issues are outlined.

Key-words: landscape, amenities, rural area, regional development, economic development

\section{* Unité de recherche Développement des territoires montagnards, Cemagref Grenoble, 2 rue de la Papeterie, BP 76, 38402 Saint-Martin-d'Hères cedex e-mail: jean-christophe.dissart@cemagref.fr}

An earlier version of this paper was presented at the annual congress of the Association of European Schools of Planning, Vienna, Austria, July 13-17, 2005.

This paper was first written when the author was with the Institut supérieur d'agriculture de Lille. The author wishes to thank the editors of this special issue as well as two anonymous referees for their rich comments and suggestions for corrections. 
$\mathrm{F}$ OLLOWING the crisis of fordism, rural areas are experiencing economic restructuring. This restructuring is illustrated by the renaissance of areas that used to be considered marginal or disadvantaged. Such areas tend to benefit from an increased and more diversified demand for goods and services that are found in rural areas (agrifood, craft, tourism), including new productive functions (environmental services).

Indeed, both in France and the United States, it is widely acknowledged that rural areas are increasingly diverse and home to various types of productions or functions (DATAR, 2003; Perrier-Cornet, 2004): The "resource" countryside features productive functions, with declining agricultural employment but increasing industry and service employment; the "nature" countryside is characterized by ecological functions including natural resource protection, biodiversity maintenance and protection against natural hazards; housing and recreation functions mark the "landscape" countryside, which also features residential economic activities. The latter has been the chief emerging figure of rural France since the 1980s.

These functions have to be taken in a relative sense given the difference in population densities between the two countries (110 vs. 31 people per $\mathrm{km}^{2}$ in 2005). Consequently, the notion of landscape differs between France or Europe and the United States: In Europe, it is something that is shaped by humans, and the notion of "wilderness", though the most obvious cultural concept of countryside in the United States (Cheshire, 1989), hardly exists.

Given their tourism, recreation and residential functions, landscapes may be considered part of the broader category of amenities. Though no unique definition of amenities exists, it is generally agreed that they present two characteristics: 1) they are site-specific, and consequently help differentiate locations; and 2) they make a location a more attractive place to live, and consequently may boost local development. In the literature, they include a wide array of elements, and range from climate to public facilities, level of crime, recreation opportunities or air quality. As such, amenities are often central to quality of life debates.

The importance of amenities (be they natural or built) in explaining regional growth patterns has become widely accepted in the development literature (e.g., OECD, 1999). In the United States, analyses have repeatedly found that areas endowed with amenities experienced higher rates of growth than the US average. For example, Graves $(1979 ; 1980 ; 1983)$ showed that taking account of location-specific amenities improved the performance of migration studies. The seminal works by Rosen (1979) then Roback (1982) suggested that amenities and quality of life factors were capitalized into wages and rents. And real estate professionals have long understood the role that site-specific qualities play in determining property values. After reviewing the planning literature, Dissart and Deller (2000) concluded that amenities and quality of life would increasingly play a significant (albeit complex) role in various development dimensions, be they place ranking, human migration, firm location or more broadly regional growth. Consequently, in rural areas that face declining employment in their traditional economic activities, amenities may provide opportunities for alternative (or supplementary support to) local activities, forming the basis for "amenity-led" development strategies (Green, 2001). 
The approach of this survey paper is to analyze the impact of landscapes on local economic development via the broader concept of amenities. Such relationships have not yet been fully described. Therefore, the paper builds on existing theories and concepts of amenities as well as empirical analyses, and intends to contribute to the literature in two ways: 1) formalize the diversity of amenities and the means by which amenities and landscapes may impact regional development; and 2) offer a review of the literature from the perspective of regional issues.

The rest of the paper is divided into four sections. The following section defines amenities and landscapes and their characteristics, particularly as economic goods. It is stressed that landscapes qualify as amenities. The next section focuses on the concept of amenity supply and demand, including the notion of joint production. Next, the links between amenities or landscapes and regional development are explained via both impact mechanisms and institutional arrangements; a survey of the literature shows that landscapes per se have hardly been the central topic of empirical analyses. It should be noted that growth and development are multidimensional in nature; many studies reported in this paper deal with population, fewer address population and employment, and still fewer deal with population, employment and income. A final section outlines key policy issues and further research needs.

\section{Amenities and landscapes: Definitions and characteristics}

In this paper, amenities are defined as location-specific features that enhance the attractiveness of a given location. Amenities have been defined in several ways, including non-marketed qualities of a locality that make it an attractive place to live and work (Power, 1988). More specifically, rural amenities refer to the hedonic aspects associated with natural and man-made features of rural areas (Marcouiller $e t$ al., 2002). Amenities provide benefits to people through the direct consumption of specific aspects of land, natural resources and human activity (OECD, 1994). As such, the range of potentially relevant amenities is broad, including natural landscape features (e.g., coastlines, topography), climate (e.g., temperature, rainfall), social characteristics (e.g., school quality, crime rate), cultural issues (e.g., traditions, cultural institutions), and the human-built environment (e.g., housing density, public infrastructure).

As mentioned before, landscapes are amenities. Indeed, following the European Landscape Convention (ELC, 2000), a landscape is defined as an area as perceived by local people or visitors, whose visual features and character are the result of the action of natural and/or cultural (i.e., human) factors over time. In addition, in its preamble, the Convention underlines that the landscape is an important part of the quality of life for people everywhere because it plays a significant public interest role in the cultural, ecological, environmental and social fields. Last, the landscape is considered a resource that is favorable to economic activity and whose protection, management and planning can contribute to job creation (ELC, 2000). 
There is consensus about the definition above because it emphasizes four chief features of landscapes that are widely acknowledged: 1) the physical reality of space, as illustrated by landforms, flora and fauna, with biogeographic units that are differently arranged; 2) human intervention, as illustrated by activities or the built environment; 3) perception (or subjectivity), due to the fact that a landscape exists whenever one looks at his/her environment as far as the eye can see; and 4) time, since landscapes are continuously changing and must be appreciated as a vision at a given point in time. This is why, again, the American concept of "wilderness" is difficult to transpose in a European context where landscapes are commonly anthropized.

Green (2001) gave four important characteristics of amenities. First, amenities are limited because of nonproductibility: Use of the amenity is restricted to a specific territory, which helps distinguish it from other territories. A second characteristic is irreversibility: The value of amenities is sensitive to change over time and it is difficult to restore it once it has been destroyed. Third, amenities are positively and strongly correlated with income. Finally, amenities are usually characterized by nonsubstitutability; for instance, a wilderness area is unique and may not be traded with another type of amenity or even another wilderness area.

Green's description of amenities may correspond to an extreme case when all characteristics are met. Indeed, there are instances of restoration or replacement of natural milieus - prairie or wetland, for example -, so that uniqueness may be limited to highly distinctive natural resources or to sites that are difficult to produce such as water bodies or mountains. Irreversibility is basically a timeline issue: Though the subject of intense debate, with time, few sites would be truly irreplaceable. Last, natural resources may have a production cost of zero, but their protection and maintenance may prove costly.

Typically, amenity values may vary considerably, are driven by human perceptions, and comprise two broad types of values: Use and nonuse (Bonnieux and Rainelli, 2000; Rambonilaza, 2004). First, use values represent the value associated with actual use (e.g., outdoor recreation). Second, in the face of irreversible consequences of some policies and uncertainties about the future, individuals may derive some value from an amenity without actually using it. Nonuse values may be subdivided into option value (the value of keeping available the option to use the amenity at a later date) ${ }^{1}$, existence value (the value that humans attach to the simple fact that a resource exists, e.g., a particular habitat, even though few may actually visit the area), bequest value (the value that humans attach to the possibility of maintaining a resource for the benefit of future generations), and shared consumption value (the value that humans attach to the possibility of maintaining a resource for the benefit of the current generation).

Amenities provide services as quasi-public goods. A pure public good is a good that meets the two following criteria (OECD, 2001): Non-excludability (it is physically or institutionally impossible, or very costly, to exclude anyone from using

\footnotetext{
${ }^{1}$ Some authors consider option values as part of use values (e.g., Pearce et al., 2006).
} 
the good), and non-rivalry (a unit of the good can be consumed by one individual without diminishing the consumption opportunities available to others from the same unit). In practice (and particularly for landscapes), it is difficult to find a good that strictly meets these criteria; hence the notion of quasi-public goods, which is the case of most goods that are not private.

The nature of landscapes and amenities as quasi-public goods and their multidimensional values make difficult their economic valuation. Their potential enhancement strongly depends, however, on the nature of the value associated with the amenity (Bonnieux and Rainelli, 2000). For example, using the market as a regulation mode seems appropriate for amenities associated with use values (e.g., tourism). In contrast, nonuse values present valuation difficulties, leading to use revealed preference (hedonic pricing, travel cost) or stated preference (contingent valuation, choice experiment) methods in order to guide decision makers.

Overall, values of natural amenities are driven by human perceptions of aesthetics associated with trees, forests, open space, water, and topography (Marcouiller et al., 2002). But the major problem confronting any valuation of aesthetics is the difficulty in unraveling aesthetic aspects of a good or experience from other aspects (Graves, 1991). Consequently, Graves (1991) identified the Contingent Valuation Method $(\mathrm{CVM})$ as a necessary, though not totally satisfactory, method for eliciting preferences. Arguments in favor of CVM include its abilities to better distinguish the aesthetic dimension of a policy-induced change, to generate data rather than relying on proxies, and to impose fewer behavior assumptions (so long as intentions accurately portray actions). Using revealed preference methods pose difficult problems: Household production methods are hardly used because of the problem of separating aesthetics from other characteristics of recreation areas; and hedonic methods face data limitation difficulties because many important aesthetic goods are located where neither labor nor land markets are well developed. All in all, both CVM and hedonic methods have a role to play in valuing aesthetics, but future research should focus on refining each method and providing cross-method validity checks (Graves, 1991).

Analyzing the valuation of landscape benefits, Rambonilaza (2004) further showed that 1) valuation was limited by the difficulty to agree on a common definition of the good to evaluate and on the nature of policies' impacts (e.g., protect landscapes or maintain farms using public subsidies), and 2) the demand for landscapes is multi-attributes ${ }^{2}$. Indeed, perception of a landscape is done via a few landmarks called landscape attributes with specific features and management mechanisms, and consumer preferences are impacted by the relationship between these attributes. However, because norms vary with individuals, social groups, cultures and periods of time, a universal norm of landscape quality does not exist (Colson and Stenger-Letheux, 1996). Norms are the result of a social construction, which underlines the fact that landscapes indeed constitute an interface between physical attributes, socioeconomic impacts, perception, and time.

\footnotetext{
${ }^{2}$ For a review of studies on landscape demand, see Rambonilaza (2004). Also, see the Environmental Valuation Reference Inventory database $(<b t t p: / / w w w . e v r i . c a\rangle)$ for an expanded list of empirical studies.
} 


\section{Amenities: Supply and demand}

\section{Supply}

Amenity-led development strategies raise questions about the supply of amenities. From a rural economic development perspective, local physical supply of attractive landscapes is not sufficient.

Consider two examples, one in France and one in the United States. In France, historically low levels of population density are found along a southwest-northeast line: The "arid diagonal". Despite varied topography, a range of climatic conditions, and attractive agricultural and natural landscapes, regions along this line (MidiPyrénés, Limousin, Awvergne, Bourgogne and Champagne-Ardenne) all exhibit density values that are lower than 60 people per $\mathrm{km}^{2}$. This is changing, though, as French southern regions all tend to gain population. Nonetheless, the five départements (Creuse, Allier, Nièvre, Haute-Marne, Ardennes) that are still losing population (at least $0.1 \%$ per year) are all located in these regions. In the US, the experience of central Alaska demonstrates, too, that physical supply (unique landscape features) is not a powerful enough force to stimulate local economic development.

Therefore, from an economic development perspective, cost (be it social, cultural or economic) is also a central component of the supply of amenities. High access costs associated with isolation or remoteness may reduce the value (for development) of amenities to zero. Put differently, access costs have to be offset by higher valued local amenities if those amenities are to support rural development (Power, 2005) 3 .

This tends to explain why rural areas that are adjacent to metropolitan areas experience stronger growth than their remote counterparts. Indeed, people try to balance amenities and disamenities associated with rural and urban locations: For example, low cost housing and landscapes but distance to services (in rural areas) vs. employment and cultural attractions but pollution (in urban areas). Consequently, those areas that can offer both, i.e., periurban areas, have to manage growth. In contrast, despite improvements in transportation and communications, remote rural areas still suffer from a lack of access and high costs of travel that hinder the potential for amenity-led economic development.

Next, the supply of natural amenities is fixed, or not, according to the time frame that is considered. In France, for example, forests covered about $90 \%$ of the landscape at the time of Gaul vs. 30\% today. Forests were extensively cleared for cultivation and to accommodate population growth from the $10^{\text {th }}$ through the $13^{\text {th }}$ centuries. Then, forest cover increased due to demographic crises (the Black Death), and decreased again because of population growth and preindustrial consumption of wood. Since the $19^{\text {th }}$ century and despite strong population growth, forests have

3 In this sense, amenities are identified at their use value, which is important for regional development purposes; nonuse values tend to be more important from a resource protection perspective. 
gained ground to the point that French forests are aging due to insufficient timber harvest. Take also the example of agricultural fields, which used to be small plots separated by hedges or shrubs. Starting in the 1960s, land regrouping destroyed those hedges in order to increase field size and make farms more competitive via economies of scale. Today, hedges are replanted in the names of biodiversity protection, soil erosion control, and aesthetics.

In the United States, shifting land use, too, characterized much of what were forestlands East of the Mississippi. Forests were first cleared for agriculture, then abandoned marginal agricultural lands reverted back to forests, and some parts of these second growth private forestlands became National Forests in the first half of the $20^{\text {th }}$ century.

Therefore, economic supply of amenities is relatively fixed in the short run, and the value of amenities for rural development depends on both the cost of isolation and the role of transportation and communication technology and infrastructure.

\section{Jointness of production}

In France or the United States, unique landscape features and scenic vistas are usually not that common across the national territory. Rather, it is agricultural and forestry activities that occupy most of the land and therefore are responsible for providing most natural amenities that people may benefit from. Indeed, agriculture and forestry display similarities (OECD, 2001): The provision of public and private goods; the importance of land as an input; the role of biological processes in production; a close relationship with the environment; and an impact on the rural economy. Consequently, the relationship between agriculture and forestry and the environment is often central to the discussion about the provision of rural amenities (Hodge, 2000).

From an economic perspective, the concept of joint production offers the perspective of combining extractive and amenity uses of the land resource base (Bowers and Cheshire, 1983; Cheshire, 1989). The question is how both uses interact. This approach ties into the concept of multifunctionality: There is increasing recognition that environmental services provided by farmers can create positive externalities, enhance the land resource base and attract temporary or permanent residents.

Thus, across France and the United States and around the world some of the most attractive landscapes are associated with decades or centuries of agriculture or forestry activity, which creates a mix of goods and services. Such services include attractive landscapes, open space, lower settlement density, wildlife habitat, and recreation opportunities. Similarly, forests may be managed for timber production, recreation, wildlife and residential settlement if the rate and method of timber extraction are chosen to be compatible with such amenity values. In contrast, there is evidence of environmental change and value loss associated with the commercial development of natural landscapes: Intensive (high-input) agriculture or short rotation silviculture has been associated with environmental damage. 
Therefore, there is a trade-off between protecting natural amenities and their commercial development as there is a trade-off between extractive and amenity uses of the land. Joint production of both natural amenities and commercial products from the natural landscape and the trade-off between the two may be illustrated by a Production Possibility Frontier (PPF), which depicts the various combinations of agricultural or forestry output and countryside services (amenities) that can be produced. The shape of the PPF will depend on the nature of the underlying technologies, and its slope measures the marginal rate of transformation: How much agricultural or forestry output one can get if one decides to sacrifice some of the amenities. Figure 1 below illustrates this trade-off.

Figure 1. Production possibility frontier between extractive and amenity uses

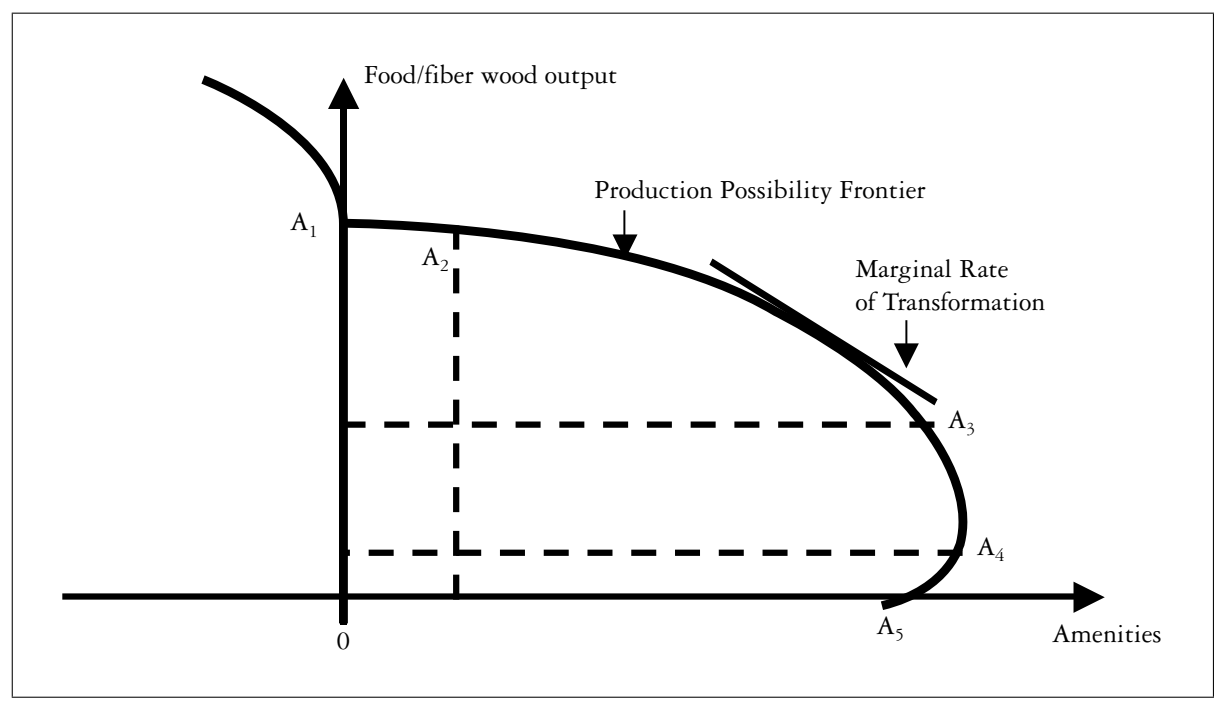

Source: After Bonnieux and Rainelli (2000)

As shown on figure 1, links between agricultural (i.e., food, fiber, wood) production and amenities are relatively complex because they are complementary or substitutes according to the situation (Bonnieux and Rainelli, 2000) ${ }^{4}$ :

$-A_{1}$ marks a significant level of commodity output with no production of externalities.

- To the left of $A_{1}$, increasing production is done via intensification of the use of land; using more inputs creates negative externalities related to excess use of fertilizers or pesticides, hence nonpoint pollution.

- From $A_{1}$ to $A_{2}$ there are several combinations of labor and capital for the same level of output. If capital is cheap relative to labor, the production system features large fields in order to work as fast as possible, where hedges and slopes are removed;

4 Use of the PPF to analyze the implications of joint production predates Bonnieux and Rainelli (2000). 
positive externalities exist due to the maintenance of open space, but they are low. If labor is cheap relative to capital, then conserving hedges and slopes is justified, and as one moves closer to $A_{2}$ the production of amenities becomes significant with a small reduction in agricultural output. The relationship between the production of commodities and amenities is weakly complementary.

- To the right of $A_{2}$ there is a reduction in commodity production while environmental quality increases. The production system changes: First, "reasoned" agriculture, then organic farming. Thus, from $A_{2}$ to $A_{3}$ the relationship between agricultural good production and environmental good production changes from complementarity to substitution.

- From $A_{3}$ to $A_{4}$ commodity production varies with an almost constant level of amenities. This case corresponds to relatively extensive animal breeding with permanent pasture and low animal density. In this situation, there is, again, weak complementarity between the two categories of produced goods.

- From $A_{4}$ to $A_{5}$ the production of agricultural goods decreases, and so does the production of amenities. There is negative complementarity between the goods. This happens with very low animal density or extensive fallow. In this case, commodity output reduction is associated with the production of wasteland and the loss of biodiversity and landscape quality.

Because it aggregates positive as well as negative externalities, figure 1 cannot illustrate all situations. Indeed, it is possible to observe negative and positive externalities simultaneously (e.g., water pollution and landscape maintenance). Joint production of commercial products and amenities is possible (figure 1), but is likely to impose constraints on traditional commodity production. Such constraints may include restrictions regarding the use of certain inputs or production practices (e.g., confined animal feeding operations). Therefore, the potential for joint production depends on what the trade-offs are and how people evaluate what is lost due to this trade-off.

All in all, joint production of goods and services is interesting for its capacity to create economies of scope: Cost savings that are generated through the joint provision of several outputs as opposed to their separate provision (OECD, 2001). Joint production is preferred in situations where there is a high degree of complementarity among outputs and where synergy may be increased (and conflicts reduced) through appropriate management decisions (OECD, 2001). In conclusion, managing natural resources may be viewed as lying along a spectrum that varies from intensive (e.g., fencerow to fencerow agriculture) to extensive (e.g., longer rotation silviculture), with different combinations of market and nonmarket outputs (Marcouiller, 1998).

\section{Basket of goods and landscape}

In order to explain location-specific external economies, Pecqueur (2001) suggested the concept of a basket of goods: Regional stakeholders may set up a strategy of production that is both varied (i.e., combining several goods and services) and located (i.e., related to a specific area, its culture and history). Based on Lancaster's approach to consumer theory, the basket of goods approach allows for various combination and separate purchase of the goods that make up the package. 
Consequently, combined goods present characteristics that are different from the sum of characteristics for each of these goods.

The model rests on three major components (Hirczak et al., 2005; Pecqueur, 2001). First, a specific supply of private goods and services over a given area. Products of the basket are complementary (e.g., olive oil and herbs) with a common geographic origin and a consistent image of quality. Production is specific because it is tied to a territory and characterized by a specific know-how and limited reproducibility. Moreover, local consumption of these products is made easier by services that facilitate access to the basket. Examples include tourism or cuisine.

Second, an inelastic demand of the "shopping" type (i.e., clients go to suppliers and choose the basket by themselves). Consumers of the basket of goods consider the area as a vector of joint purchase of products and services. Through experiences as diverse as restaurants, farmers' markets or cultural visits, preferences that are expressed directly for local products or services also indicate an indirect preference for the area itself, including its reputation and traditions, thus rendering demand little price-elastic.

The third component of the model is public goods. The regional context is critical to the basket, so much so that public goods (the environment, landscapes and biodiversity, but also architecture, history and traditions) act as a sort of "case" (écrin) and "staging" (mise en scène) for the products. Consequently, the basket is not merely a juxtaposition of private goods but indeed a combination of public and private goods and services.

In this perspective, products, services, and landscapes are interrelated ${ }^{5}$. There is a symbiotic relationship between the basket and its territory: The lead product attracts consumers who also appreciate its complementary products, which reinforces the locale's quality image. Anticipating the link with regional development, producers of the basket of goods internalize location-specific positive externalities due to the supply of landscape and, more generally, amenities.

\section{Demand}

The demand for amenities depends on several factors. First and directly related to supply, changes in transportation and communication technology and infrastructure have greatly reduced the costs associated with access to physical supply of natural amenities, especially those located in remote rural areas. These improvements have allowed for greater satisfaction of the demand for amenities over time. Whereas rural economies have changed at a quick pace over the last decades, when striking changes in transportation and communications occurred, the supply of (natural) amenities is relatively fixed in the short-run. This helps explain why amenities, nowadays, play a greater role in regional development than before.

Second, there are "push" factors from metropolitan areas that are associated with air pollution, traffic congestion, a stressful way of life, etc. This tends to be

\footnotetext{
5 The link between official signs of quality and landscapes has also been shown (Gauttier, 2006).
} 
compounded by both increased environmental awareness and demonstrated links between environmental quality and public health. For example, as young families and retirees moved to southern locations in search for a better living environment, the Paris region recorded a negative migratory balance over the 1999-2004 period. In the United States, older industrial cities in the Northeast have experienced population decline to the benefit of Sunbelt states. As the value of a given area's amenities is measured relative to amenities associated with other areas, it suffices that urban populations perceive a worsening of urban living conditions to increase, ceteris paribus, the relative value of amenities associated with rural areas. This contributes to explain population shifts both locally (from central cities to the suburbs) and nationally (from major metropolitan areas in the North to warmer, less dense locations in the South and West).

Third, as reported earlier, the demand for natural amenities is positively correlated with income. As consequences of rising incomes for a significant portion of the population, and following the economic expansion of the 1990s, Green (2001) reported an increase in seasonal and second-homes, outdoor recreation activities, and early retirements, which all fueled the growth of US amenity areas.

People have been sensitive to landscape attributes for a long time, obviously, and amenities have played a role in regional development for over a century as illustrated by the development of the Riviera resorts or alpine skiing in the $19^{\text {th }}$ century. This role is as much a matter of growing disposable income and leisure as it is of falling travel costs. At a more local level, rural amenities were one of the drivers of early suburbanization. At the same time "push" factors such as pollution and congestion have always been symptomatic of industrial cities; but there were also benefits of agglomeration and enhanced choice. In addition, urban decentralization was a major trend from the 1950s but has actually fallen back since 1990 with some large cities in both the US and Europe experiencing population growth. This is arguably due to the city as an amenity for living described by Glaeser et al. (2001), which underscores the role of cities for consumption (be that social contact, aesthetically pleasant buildings or major sports events), and probably associated with the decline of industrial activity in advanced economies' cities ${ }^{6}$.

What has changed is that enjoyment of amenities is now available to a much larger share of the population. Early development of the Riviera and alpine resorts was due to wealthy individuals, mostly British gentry. But several factors converged to make amenities enjoyable by more people: Implementation of paid vacation (1936 in France), increase in leisure time, strong economic growth, and investments in infrastructure (ranging from transportation to accommodation for tourism). As a result, neither farming nor manufacturing but amenities and services have become drivers of regional and rural growth, after decades of rural decline and exodus. This is true also of periurban areas where rural amenities first attracted the upper-class leaving the polluted and congested city of the industrial revolution. Periurbanization, however, took place progressively (after World War II in the US, in the early 1970s in France)

6 The author thanks one of the anonymous referees for this comment. 
as a result of higher incomes, acquisition of home equipment (cars and refrigerators), investment in infrastructure (roads), and relative land prices. Last, rising environmental concern and awareness keep fueling the demand for amenities.

Fourth, as new tastes develop, people's preferences change over time and so does the demand for amenities. In the United States, Power (2005) explains striking changes regarding the perception of desert landscapes over time: They used to be considered monotonous, dangerous and therefore uninhabitable landscapes, whereas now they are popular migration, winter and retirement destination. For example, between 2000 and 2004, the fastest growing city with at least 100,000 people was Gilbert, a Phoenix (Arizona) suburb, which grew 42 percent!

Fifth, technology impacts the demand for amenities. Using the same example, climate plays an important role in the growth of the desert Southwest, with sunshine and low humidity. But this attractiveness is reinforced by technological development (access to relatively low cost air conditioning) that allows residents to turn what had been a disadvantage (intense sunshine and high temperatures) into an amenity that can be adjusted for personal comfort.

Sixth, public investments, too, play a role in stimulating the demand for amenities. This was first stressed in the previous section. This may also be shown by considering the example of the Mediterranean Sea as a vacation spot. Prior to the 1960s, the Languedoc-Roussillon portion of the Mediterranean coast used to be a semidesertic, difficult of access, mosquito-infested, wetland ridden area (Monod and Castelbajac, 2002). Only a limited number of campers visited that area during summertime. The French government commissioned massive development projects: Wetland drainage, water servicing, tree planting, and harbor and resort construction. These public works effectively changed that portion of the coast and people's perception of it, so much so that it met much of the baby boomers' vacation destination demand during the 1970s and the 1980s. In addition, today, the Languedoc-Roussillon region presents one of the highest net migration rates.

Last, rural areas have changed, not only economically but also socially. What used to be sparse, homogeneous settlements of farmers have experienced economic, social and cultural restructuring that have moved them closer to mainstream society. This was facilitated by a number of factors, including spousal off-farm work, economic diversification of rural areas, and in-migration from urban areas. Rural areas have become less isolated and more integrated with society at large. Consequently, the meaning of "rural" has changed, and moving to a high-amenity, remote rural area requires increasingly less adaptability because rural areas are becoming more alike the rest of the nation.

\section{Amenities, landscapes and regional development}

As people increasingly value amenities and amenities are distributed unevenly across regions, it is reasonable to hypothesize that amenities and landscapes play a role in regional development. Empirically, this hypothesis has not been rejected. Indeed, landscapes may provide additional sources of economic activity for rural areas 
that face decline in both population and traditional, extractive activities, but are endowed with amenities. The issue, then, is to describe how to go from the presence of amenities to increased local development. This is addressed by considering, first, the empirical literature on amenities or quality of life and regional development; second, impact mechanisms of amenities on local economic activities; third, the role of institutional arrangements and public policies on such impact mechanisms; and fourth, a summary of the processes by which landscapes may foster local economic development.

\section{Amenities, quality of life and regional growth}

As they contribute to local quality of life, amenities and landscapes constitute factors of regional growth, along with other environmental, social and economic factors. In the regional science literature ${ }^{7}$, the relationship between amenities and regional development has been addressed via four main perspectives, namely human migration, place ranking, firm location, and regional growth.

Theories of migration identify two main types of determinants: On one hand, family and life-cycle considerations (e.g., Currie and Halli, 1989); on the other hand, application of disequilibrium vs. equilibrium perspectives. The disequilibrium, or human capital approach, considers that individuals invest in their education and pursue economic opportunities wherever they are (see, e.g., Cebula and Vedder, 1973; Kahley, 1991). In the equilibrium perspective, utility-maximizing individuals are willing to accept lower wages provided compensation by a wider range of amenities. Migration results from a change in the demand for (nontraded) amenities. This approach is based on the pioneer works by Rosen (1979) and Roback (1982) who established implicit prices (in both the labor and housing markets) for amenities that supposedly reflect the quality of life in a given location.

The issue of the relative importance of economic vs, amenity factors as determinants of migration is still open, but most empirical studies show a significant role of amenities (Graves, 1983, 1980, and 1979; McGranahan, 1999; Reichert and Rudzitis, 1992). Migration to rural areas, in particular, has been linked to several factors, including quality of life factors such as lifestyle change, better environmental quality, cheaper standards of living, and recreation opportunities (Beesley and Bowles, 1991; Greenwood, 1985). In particular, there is evidence that amenity-rich regions have attracted in-migrants at disproportionately high rates in the United States (Johnson and Fuguitt, 2000; McGranahan, 1999).

As an illustration, Mueser and Graves (1995) examined the extent to which US migration over the $1950-80$ period was determined by economic opportunity

7 Links between landscapes and regional development have been analyzed under various perspectives. A significant part of the literature, largely originating from environmental economics, aims at identifying use and/or nonuse landscape values. Such analyses, however, tend to ignore some impacts of the landscape on regional development, including those related to employment. 
(migrant labor demand) or residential amenities (migrant labor supply). They found no definite answer regarding the causal impact in migration because the relative importance of profit-shifting $v$ s, utility-shifting variables changed from one period to the next. They concluded, however, that systematic migration trends appeared related to household preferences for amenities, in conjunction with changes in income or technology that increase the importance of such factors.

Using a sample of movers, Clark and Cosgrove (1991) tested the relative importance of the two major categories of determinants of migration. They found that both human capital (education, experience, wage) and quality of life (climate, location on an ocean coast, pollution, congestion, crime, sports and arts conditions) factors were significant in explaining regional migration: Migrants were willing to move greater distances for higher level of amenities or better opportunities. In a subsequent study, Clark and Hunter (1992) integrated three types of determinants (economic opportunities, amenities, and fiscal factors) of migration into a life-cycle framework. Using a countrywide model of white male migration over the 1970-80 period, they found life-cycle patterns: Economic opportunities were most influential during males' working years; older migrants were more attracted to amenable locations than their younger cohorts; and high income taxes detracted working males in their peak earning years while all migrants aged 55 to 69 avoided counties in states with high inheritance and estate taxes.

The disequilibrium approach has been used to calculate indices of quality of life and produce rankings of urban places (Berger and Blomquist, 1988; Blomquist et al., 1988; Giannias, 1997 and 1996; Gyourko, 1991; Gyourko and Tracy, 1991; Stover and Leven, 1992). Gyourko et al. (1999) reviewed the recent research about urban quality of life, focusing on the estimation of implicit prices of environmental attributes. They questioned the convenient assumption that local land and labor markets are in states of long-run equilibrium in any cross-section of data, and concluded on the necessity to assemble higher quality databases in order to produce more precise measures of overall quality of life values and rankings.

Next, the literature on firm location opposes two perspectives (Blair and Premus, 1987; Gottlieb, 1994). First, classic location theory suggests that firms choose locations that maximize profits or minimize costs (transportation costs in particular). Second, quality of life aspects impact firm location. Indeed, given an activity shift away from industry toward services, communication improvements, and the growing importance of skilled labor, recent studies suggest there is a shift from minimum cost to quality of life considerations. Location determinants have been tested using two methods: Surveys (e.g., Foster, 1977; Hart et al., 1989) and econometric studies (e.g., O' hUallacháin, 1990). Results from these two approaches generally agree and indicate that economic factors of location (market, labor force) are more important than quality of life factors, but increasingly less so (Blair and Premus, 1987).

Third, one may consider that economic growth happens as the result of both human migration and firm location (Knapp and Graves, 1989). Reviewing the empirical literature on regional growth factors, Kusmin (1994) found that conclusions were sensitive to methodological issues. From an economic development perspective, Wong (1998) found that traditional economic factors (e.g., land, labor) 
must be satisfied before intangible factors (e.g., business culture, quality of life) are considered.

Using simultaneous equation modeling, Carlino and Mills (1987) analyzed the impact of economic, demographic and climatic variables on population and employment growth. Their results showed, among others, that amenities influenced county population and employment levels. Using the same approach, other studies indicated a significant but complex role of amenities in regional economic growth and development, both in terms of employment and population (Boarnet, 1994; Clark and Murphy, 1996; Crown, 1991; Henry et al., 1997; Schmitt et al., 2006). Following Carlino and Mills (1987) and Clark and Murphy (1996), in particular, Duffy-Deno (1997a; 1997b; 1998) found no negative impact of the Endangered Species Act, State Parks and federally-owned wilderness areas on population and employment growth in western US rural counties.

To be noted is the contribution of Deller et al. (2001) who assessed the role of amenities and quality of life in US rural economic growth as indicated by change in population, employment, and per capita income. Based on county-level secondary data, they used principal components analysis to derive five amenity vectors: Land, water, winter, climate, and developed recreational infrastructure. They integrated these components with other regional development factors (markets, labor, government) into a structural model of regional growth, and showed positive relationships between amenities and local economic performance.

It should be acknowledged, however, that most studies addressing amenity impacts on regional growth do not include landscape variables per se. Examples abound. Thus, a common proxy for amenities is climate: Graves $(1979 ; 1980)$ used temperature, humidity, and wind velocity to describe location-specific attributes. Carlino and Mills (1987) proxied amenities by dummy variables: Regional dummies for climate, and county location dummies for congestion, environmental quality, desire for small-town living, etc. Using factor analysis, Henry et al. (1997) reduced twelve variables to six in order to reflect local attributes that impacted business and residential location decisions; common to both were distance to the urban core, proportion of poor households, pupils per teacher ratio, and access to public services (water and sewer facilities). Last, the review of urban quality of life by Gyourko et al. (1999) showed a focus on environmental attributes (climate, pollution) and service amenities (police, fire, health, schooling, crime); this might be due to data limitations, but no attention was given to the urban landscape (e.g., parks, architecture, skyline).

A more recent literature on rural issues takes better account of landscapes. Thus, McGranahan (1999) used a natural amenity index based on climate, topography and water area and found that natural amenities were highly related to rural county population change over the 1970-96 period. In addition to climate, the principal components used by Deller et al. (2001) were based on landscape-related variables such as parks, acres of mountains, cropland, pasture and range land, forests, wetlands, streams and water bodies, or river miles. Last, English et al. (2000) found that local economic dependence on tourism in US rural areas was clearly tied to proximity to 
certain types of natural resources (hence landscapes), including beaches, lakes, forests, and mountainous terrain, and that tourism-dependent counties experienced greater increases in population growth, per capita income growth and housing construction than other rural counties. Overall, recreational homeowners, retirees, tourists create much of the demand for development in amenity-rich areas (Marcouiller et al., 2002). There is evidence, nonetheless, that outdoor recreation facilities do not contribute significantly to the economic development of US remote rural counties (Dissart, 2005).

In France, Vollet (1998) found that employment growth due to residential and recreational activity only partly offset agricultural and industrial employment decline in selected rural areas. Vollet and Dion (2001) also found that basic employment linked to recreative functions in Massif central tourism areas represented a small weight. In a rural area located in the center of France, Vollet and Guérin (2005) found that the cumulated impact of the landscape represented about $2 \%$ of local employment, thereby showing the real but limited impact of the landscape in economic development. More generally, those areas where people go for leisure and consumption tend to be more dynamic - because of both recreation activity and inmigration - than large metropolitan areas (especially the Paris region) where the quality of life is worsening (Davezies, 2004).

From a specific rural $v$ s. urban perspective, the literature on human migration features two broad types of studies. First, in a disequilibrium perspective, hedonic modeling of amenities has established quality of life rankings of cities, metropolitan areas, and urban counties. Stemming from the works of Rosen (1979), then Roback (1982), these analyses include those of Berger and Blomquist (1988), Blomquist et al. (1988), Giannias (1997 and 1996), Gyourko (1991), Gyourko and Tracy (1991), and Stover and Leven (1992). Second, studies on the impact of amenities on migration are less centered on urban areas. For example, analyses by Graves (1983; 1980; 1979) focused on Standard Metropolitan Statistical Areas, Mueser and Graves (1995) on US county aggregates, and McGranahan (1999) on US rural counties.

Studies regarding population and employment growth feature both urban and rural units of analysis. Such studies started with the seminal work of Carlino and Mills (1987) on all US counties, which was augmented by Boarnet (1994) on municipalities in New Jersey, and by Clark and Murphy (1996) on all US counties. This modeling approach also inspired Duffy-Deno's work (1998; 1997a; 1997b) on western US rural counties and Deller et al.'s (2001) analysis of all US rural counties. Last, this approach was used by Henry et al. (1997), then Schmitt et al. (2006) to address periurban issues in Functional Economic Areas (FEAs) of the southern US and eastern France, respectively. Thus, Henry et al. (1997) found a mix of spillover and backwash effects from urban core and fringe areas to their rural hinterlands. But in FEAs with a pattern of urban decentralization, they found that rural population and employment grew faster than average over the 1980-90 period. Applying a similar approach to French FEAs, Schmitt et al. (2006) found that urban spread effects to rural areas were more likely than urban backwash effects, and that spatial urban externalities affected both rural population and employment growth.

In conclusion, the literature suggests that amenities play a stronger role in population change than in firm location. Amenities significantly impact population 
and employment growth, with a debate regarding what comes first. Results about per capita income growth are more difficult to generalize since few studies address this dimension of regional growth. Deller et al. (2001) found a significant impact of amenities and quality of life on per capita income growth in US rural counties. Focusing on neither amenities nor rural areas, Glaeser et al. (1995) found that per capita income and population growth moved together in a cross-section of US cities over the 1960-1990 period. Evans (1993), however, disputed the connection between population and per capita income growth, at least in a European context.

\section{The means: The impact mechanism}

Green (2001) presented a typology of four possible relationships between amenities and development. The first one is that development leads to the destruction of amenities. This relationship is likely to occur when a region endowed with natural resources that are sensitive to growth experiences rapid population or employment growth. The opposite relationship, i.e., that non-development leads to the destruction of amenities, is, however, possible: Amenities such as historic sites or recreation areas may require a minimal level of support (that depopulation may compromise) for their maintenance. A third possibility is that preservation of amenities may lead to non-development: Activities supporting the preservation of amenities, such as setting land aside for a park, may lead to a decline in the economy. The final possible relationship is that preservation or promotion of amenities leads to development. Eco-tourism projects, for example, both preserve the natural environment and help maintain the local population and economy.

There are several ways in which local amenities impact local economic development. Power (2005) distinguished five types of groups with an influence on regional development: Tourists, second-home owners, retirees, working-age inmigrants and relocating businesses. Each may be seeking something different and have a different impact on rural communities.

First, amenities draw tourists, i.e., temporary visitors who want to enjoy local amenities. Businesses focused on serving these visitors' needs may be created or expanded. Some visitors are more regular and persistent and build second-homes to use during their visits. The spending of these visitors supports local businesses. Third, retirees may also be attracted to high-amenity areas. They can choose to reside in the location that appeals most to them, without regard to employment opportunities. Such choices by retirees contribute to boosting local population and spending (via lower - but more stable - transfer income).

These three means are consistent with the economic base view of the local economy. In this perspective, local development is stimulated by external demand, that is, by the injection of additional income from the outside into the local economy. Additional income originates from an export activity (i.e., the extraction of resources from the natural environment for export to external markets) and is circulated throughout the economy to generate additional employment via multiplier impacts on locally-oriented businesses. For example, English and Bergstrom (1994) showed that a recreation site contributes to a region's economic 
growth through household purchases of trip inputs (both trip-specific inputs and durable recreation equipment).

The impact mechanism of tourism, in particular, has been described (Echevin and Gerbaux, 1999; English et al., 2000). Most tourism expenditures fall into four economic sectors: 1) lodging (hotels, motels and campgrounds), 2) eating and drinking (restaurants and bars), 3) retail (grocery stores, gas stations, gift shops), and 4) leisure and recreation services (ski areas, golf courses, amusement parks). These expenditures constitute the starting point of a chain reaction, with three types of revenue impacts. First, direct revenues are the set of profits, salaries, and various forms of rents that are directly related to tourism activity (e.g., wages given to hotel employees). Second, indirect revenues are distributed to suppliers and customers of tourism units (e.g., fresh produce purchases by a local restaurant). Third, induced revenues result from an increase in the purchasing power of residents (e.g., the employee of a hotel makes purchases in the area, which leads to additional revenue distribution).

Power (2005) argues that local amenities can also spur the local economy by attracting 1) in-migrants of working age who take up residence in the area and create their own job ${ }^{8}$, and 2) businesses that choose to relocate to high-amenity areas. This mechanism is different from the economic base model: A labor demand model in which workers and their families move to where the jobs are. Local amenities may also attract workers who create an attractive labor supply that draws economic activity: Jobs may also follow people. In this less conventional view of economic development, environmental quality stimulates local economy activity by attracting workers and business to the area, thereby increasing local economic diversity and creating employment and income. The hypothesis of jobs follow people vs. people follow jobs has spurred considerable debate in the regional science literature, and there is evidence that population and employment growth are interrelated (Carlino and Mills, 1987).

Overall, amenities and landscapes tend to play an increasingly significant role in the development of communities. Both views (economic base and the alternative) of the impact of amenities on local economies are complementary. Landscapes, in particular, are considered economically valuable by more than just temporary visitors.

\section{Institutional arrangements and public policy}

Public policy and institutional arrangements impact amenities and commodity development of landscapes, as well as the potential for amenity-driven local development.

As explained before, the basket of goods approach rests upon a match between location-specific supply and demand. By internalizing external effects due to specific

8 Among those are the so-called "lone eagles": self-employed individuals who can work wherever they want and who use information technologies to sell products or services to a nonlocal market. 
resources, a rent of territorial quality is created and adds value to a territory's features and its associated quality goods and services (Mollard, 2001). The rent of territorial quality is institutionally built and organizational in nature. It is a condition for the basket's sustainability, and it benefits both public and private stakeholders, including producers of lead and complementary goods and services (Lacroix et al., 2000; Mollard, 2003 and 2001; Pecqueur, 2001). Such a rent reflects the capacity of stakeholders to create institutional processes that capture the consumers' willingness to pay associated with the environment (in a broad sense) of the product. In other words, enhancement of local resources relies on the capacity of stakeholders to set up an institutional context where the consumer's purchasing act will associate the product to services.

To achieve regional development objectives, coordination between private and public stakeholders is critical at three levels (Hirczak et al., 2005):

1) Between private stakeholders, whose products' complementarity, quality and specificity should keep the rent sustainable in the face of competition.

2) Between public policies, whose consistency and level of funding should ensure appropriate policies regarding product quality, public service provision, environmental resource protection, and marketing effort.

3) Between private and public action: Balance and consistency must be found between the two in order to organize nonmarket services and to strengthen the links between product and territory.

Examples of institutional arrangements that contribute to the rent of territorial quality include collective governance of the lead product, product differentiation via official signs of quality, local markets with direct product marketing, or public funding and technical support. Specific institutional initiatives are illustrated by web marketing, discovery routes, educational programs about the territory and its associated products, landscaping and signage, and cultural events.

In conclusion, the more specific the territorial resources, the more likely the creation of externalities, and the more likely their combined supply will become a basis for a price differential (Mollard, 2003). Applying these conclusions to the issue at hand, the potential for the existence of a rent of territorial quality (and thereby the potential for regional development) increases as a given region differentiates (from the rest of the world) and coordinates (over its territory) its resources (public and private goods and services, landscapes included) with the objective of creating a location-specific supply-demand combination.

\section{Tying it all together}

To sum up this section, figure 2 shows the processes by which landscapes may foster local economic development.

On the left of figure 2 the box "supply of amenities" makes a distinction between natural and human-made amenities; as they result from the action of natural and/or human factors, landscapes lie at the intersection of the two. The demand for 


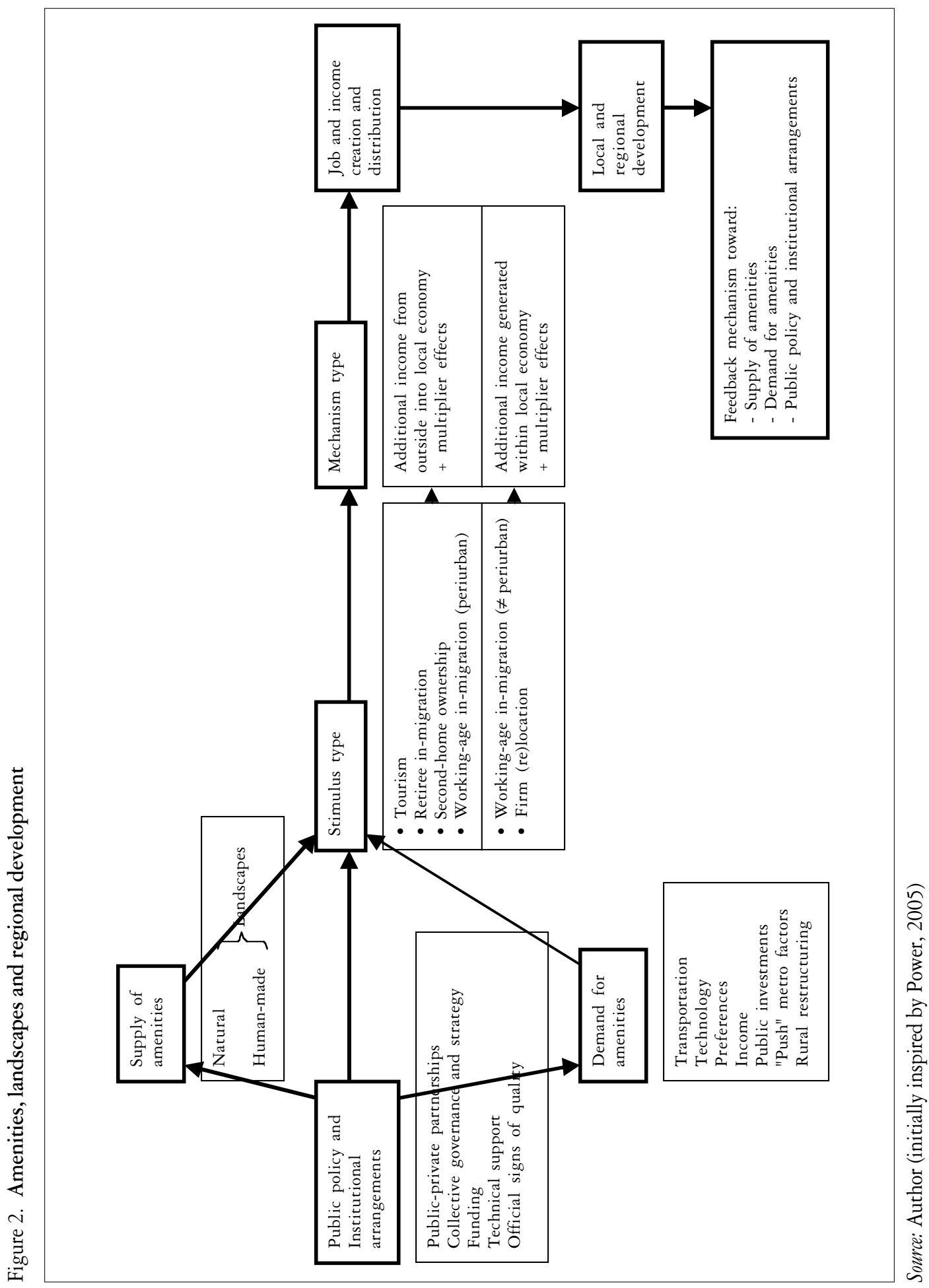


amenities depends on a number of factors: Transportation, technology, income, preferences, public investment, "push" factors from metropolitan areas, and rural restructuring. Public policy and institutional arrangements (via public-private partnerships, collective governance and strategy, funding, technical support, and official signs of quality) impact supply (e.g., development of natural areas with recreation facilities) and demand (e.g., highway improvement) for amenities as well as six types of stimulus that may lead to local development.

Stimuli are various groups with an influence on regional development. These types are the same listed by Power (2005) but further differentiated: Working-age in-migrants may be those who live in proximate rural areas but commute to their job located in the city, or those who choose to live and work in more remote rural areas. Both groups choose to live closer to rural amenities, landscapes being central to that choice, but their impact mechanism differs (see infra). Therefore, there are six stimulus types: Tourism, retiree in-migration, second-home ownership, working-age in-migration (periurban), working-age in-migration (not periurban), and firm (re)location, depending on whether an existing company chooses to relocate closer to amenities or whether its founder chooses to create it in an amenity-rich region.

There are two main mechanism types by which landscapes, via the stimulus types outlined above, may impact local and regional development. Both rely on an impact mechanism, but differ on the source of additional income. In the classic, export-base, people follow jobs model, which is triggered by tourism, retiree in-migration, second-home ownership, or working-age in-migration (periurban), the additional source of income comes from outside the community and is injected into the local economy with multiplier effects (direct, indirect, induced) ${ }^{9}$.

In the less conventional, based on environmental quality, jobs follow people model, which is triggered by working-age in-migration (not periurban) or firm (re)location, the additional source of income comes from within the local economy, with the same types of multiplier effects.

Both types of impact entail job and income creation which, if appropriately distributed, eventually leads to local and regional development. Obviously, the causality relationship does not work one-way only: Increased local economic development also impacts supply of amenities, demand for amenities and public policy and institutional arrangements via a feedback mechanism, with economic, social and environmental aspects.

The potential for creating a rent of territorial quality depends on the extent to which a specific set of amenities (including landscapes) meets a specific demand for this set. If so, and if adequate institutional arrangements are in place (e.g., coordinated public-private partnerships), then there is potential for increased, higherthan-normal job and income creation (relative to the average situation depicted in

9 A theoretical development by McGregor et al. (2000) showed that the economic base multiplier also depends on supply factors, so that both demand and supply impact the export sector. 
figure 2), and therefore increased potential for local and regional development. The issue of "specific" (supply or demand) is qualitative in nature and must be appreciated on a case by case basis.

\section{Conclusion}

In the search for forward-looking policy strategies, building on amenities and landscapes is emerging as an important area of policy action, supplementing traditional, agriculture-oriented rural policies and placing rural policy in the broader field of regional development (OECD, 1999). Because many natural and cultural features are public goods, with limited markets and hazy property rights, public policies are needed to strike the delicate balance between supply and demand, between use and conservation (OECD, 1999). This is not easy because of the many, multidimensional issues that amenities, landscapes and regional development raise in terms of both policy and research.

First, the diversity of groups responding to amenities necessarily complexifies the issue of striking a balance between protection of amenities and their commercial use. Different groups, particularly temporary vs, permanent ones, presumably have different expectations, and these expectations are likely to be different from those of the "been-here" population who resided in the area before recent interest in amenities arose (Spain, 1993). This means also that spatial planners face a new breed of economic, social and environmental issues brought about by a change in land use that is driven, in large part, by demands for rural residential developments and recreationally-oriented land uses (Marcouiller et al., 2002). Given that no universal norm of landscape quality exists, finding common ground - via participatory processes, for example - should be part of the local planning policy agenda.

Second, a common problem for rural areas that attempt to build their economies on amenities is a potential for too much growth promotion that might destroy the amenities that attracted economic activity to the area in the first place. If communities are dependent on amenities as the basis of their economy, striking a balance between growth and preservation is critical. Consequently, community development practitioners should first convince local residents and elected officials to consider their specific resource an amenity rather than a resource to extract for the benefit of external demand. Also, following Davezies' (2004) demonstration of increasing divergence between areas of production vs. consumption, local development practitioners should focus more on tapping consumer spending, and not necessarily attracting productive activities.

Third, a better understanding of how amenity-based development strategies address equity issues is needed. There is much evidence that amenities drive population growth, but little evidence regarding the impact of amenities on distribution indicators such as poverty or income inequality. As environmental protection may displace (or prevent the location of) some economic activities, a related issue is job quality: Are "amenity-friendly" jobs as interesting in terms of wages and benefits as those found elsewhere? Last, as communities experience 
population growth, there are often attempts to limit residential development, which tends to increase housing prices and reduce the availability of low- and moderatepriced housing.

Designing an effective landscape policy is, to say the least, complex. To expand policy options, Moquay (2005) suggested three chief ways to act on landscapes: Education, direct intervention, and action on social and economic processes that impact landscapes. Indeed, Chassany (2005) pointed out that policies with the largest impacts on the landscape are not necessarily those that specifically target it. Landscape change, for instance, is a function of change in farming activity, which is more impacted by agricultural policy (including market regulation) than by landscape-specific policies (e.g., hedgerow planting). Moreover, as policies and their objectives change from time to time, landscapes are the complex result of temporally overlapping policies. These results point to European and national issues regarding landscape policy.

Fourth, landscapes should be given a more central position in European rural policy. The 2007-2013 EU rural development program creates a single fund, EAFRD (European Agricultural Fund for Rural Development), which replaces FEOGA to finance the Common Agricultural Policy's second pillar (rural development). This tool finances several axes, and landscape issues are mainly addressed under axis 2 (land management and the environment) via measures to protect and enhance natural resources, high-nature value farming, forestry systems and rural Europe's traditional landscape (i.e., farmed landscapes and forests). Specific measures include Natura 2000 agricultural and forest areas or support for nonproductive investments (ECDGARD, 2006).

We are still far, though, from a specific European landscape policy: The minimum share of EAFRD funding for axis 2 is $25 \%$, and landscapes are not specifically listed but rather diluted under measures aimed at fostering the sustainable use of agricultural or forestry land. Indeed, objectives of EU rural development policies have shifted from sectoral to territorial ones, but taking account of landscapes is done in a limited - though increasing - fashion for the time being (Guérin, 2005). Increased consistency is needed, in particular, between CAP's first and second pillars, so that, for examples, incentives for wet meadow maintenance are no longer at odds with corn subsidies.

Fifth, French landscape policy could be reinforced in several ways. French landscape policy has changed from a selective, elitist vision to more everyday life concerns over the 20 $0^{\text {th }}$ century (Davodeau, 2005). The landscape law of 1993 has introduced landscape criteria into protection zoning (ZPPAUP) and building permits and reinforced the role of Regional Nature Parks -via their charterregarding landscape management. Overall, there has been a progressive implementation of a real landscape policy aiming at long-term protection of the diversity of French landscapes and, with the exception of farm policy, many landscape protection tools are in the hands of local units of government. Accordingly, landscape policy could be strengthened in four ways: 
- Take time more into account. Public policies have been changing rapidly for the last 50 years, with significant impacts on the landscape. Landscape policy is difficult due to the different time scales between human decisions and environmental processes. More stability is needed because there are threshold effects in landscape change, so decision makers as well as populations must decide what legacy they want to leave for future generations (Chassany, 2005).

- Develop protection packages of landscapes in periurban areas, where most of the growth occurs. Based on a comparison of French and US approaches, Dissart (2006) suggested several ways to complement the French toolbox with a combination of regulatory and incentive approaches to protect farmland, forestland and more generally open space. Implementation and effectiveness of the selected measures depend on coordinated efforts at all levels of government, landowners and spatial planning stakeholders, but also on the integration of economic, social and environmental issues in a complete protection package.

- Develop incentives to maintain or increase the provision of valuable landscape attributes. Using an institutional economics perspective, Lippert (2006) presented a framework distinguishing monetary vs, non-monetary and direct $v$ s. indirect remuneration, and discussed transaction costs associated with remuneration arrangements. To Vollet and Guérin (2005), minimization of landscape change over time implies that those who contribute to constituting the landscape (farmers, local units of government, landscape maintenance businesses) benefit from its economic impacts; this means that landscape-oriented policies should be partly designed and financed at a greater scale than the multimunicipal level.

- Improve conflict management tools in periurban areas. Davodeau (2005) highlighted the difficulties of landscape public policy: How to intervene on public land only? How to impose restrictions on the use of private land without creating conflicts? Landscape management entails dealing with power relationships. Davodeau (2005) suggested local associations or cultural policy as tools that may increase the feeling of identity within periurban areas and thus reduce the probability of conflict.

Literature and concepts presented in this survey article have shown the diversity and complexity of amenities and landscapes, their supply and demand characteristics, and the links between amenities and landscapes and regional development. It seems that the discussion about the contribution of amenities to local development has tended to overlook, in the United States, the importance of institutional arrangements that may work to enhance amenities and local economic development, whereas, in France, the discussion may not have taken sufficiently into account the impact of working-age amenity migrants and business relocation (i.e., may have focused too much on an economic base approach). Given the complexity of the interactions between amenities and landscapes and regional development, and their potential contribution to sustainable community development, both aspects (institution building and an environmental quality view of the local economy) probably need to be taken more into account. 


\section{References}

Beesley K.B., Bowles R.T. (1991). Change in the countryside: The turnaround, the community, and the quality of life, The Rural Sociologist, 11(4), pp. 37-46.

Berger M.C., Blomquist G.C. (1988). Income, opportunities, and the quality of life of urban residents, in: Urban Change and Poverty, McGeary M.G.H., Lynn L.E. Jr. (eds), Washington DC, National Academy Press, pp. 67-101.

Blair J.P., Premus R. (1987). Major factors in industrial location: A review, Economic Development Quarterly, 1(1), pp. 72-85.

Blomquist G.C., Berger M.C. and Hoehn J.P. (1988). New estimates of quality of life in urban areas, American Economic Review, 78(1), pp. 89-107.

Boarnet M.G. (1994). An empirical model of intrametropolitan population and employment growth, Papers in Regional Science, 73(2), pp. 135-152.

Bonnieux F., Rainelli P. (2000). Aménités agricoles et tourisme rural, Revue d'Economie Régionale et Urbaine, 5, pp. 803-820.

Bowers J.K., Cheshire P. (1983). Agriculture, the Countryside and Land Use: An Economic Critique, London and New York, Methuen.

Carlino G.A., Mills E.S. (1987). The determinants of county growth, Journal of Regional Science, 27(1), pp. 39-54.

Cebula R.J., Vedder R.K. (1973). A note on migration, economic opportunity, and the quality of life, Journal of Regional Science, 13(2), pp. 205-211.

Chassany J.-P. (2005). Paysage et évaluation de politiques: quelles entrées, quelles difficultés ?, Paper presented at the final meeting of the research program on Politiques publiques et paysages, Paris, October 20-21.

Cheshire P. (1989). Applying economic rationality to problems of rural land management: A European perspective, in: Renewable Natural Resources: Economic Incentives for Improved Management, Pearce D.W., Bromley D.W. (eds), Paris, OECD publishing, pp. 136-146.

Clark D.E., Cosgrove J.C. (1991). Amenities versus labor market opportunities: Choosing the optimal distance to move, Journal of Regional Science, 31(3), pp. 311-328.

Clark D.E., Hunter W.J. (1992). The impact of economic opportunity, amenities and fiscal factors on age-specific migration rates, Journal of Regional Science, 32(3), pp. 349-365.

Clark D.E., Murphy C.A. (1996). Countywide employment and population growth: An analysis of the 1980s, Journal of Regional Science, 36(2), pp. 235-256.

Colson F., Stenger-Letheux A. (1996). Évaluation contingente et paysages agricoles : application au bocage de Loire-Atlantique, Cabiers d'économie et sociologie rurales, 39/40, pp. 151-177. 
Crown W.H. (1991). Migration and regional economic growth: An origin-destination model, Economic Development Quarterly, 5(1), pp. 45-59.

Currie R.F., Halli S.S. (1989). Mixed motivations for migration in the urban prairies: A comparative approach, Social Indicators Research, 21(5), pp. 481-499.

DATAR (2003). Quelle France rurale pour 2020 ? Contribution à une nouvelle politique de développement rural durable, Paris, la Documentation française.

Davezies L. (2004). Développement local: le déménagement des Français. La dissociation des lieux de production et de consommation, Futuribles, 295, pp. $43-56$.

Davodeau H. (2005). Les paysages, une nouvelle préoccupation dans la gestion des espaces périurbains, Cabiers d'économie et sociologie rurales, 77, pp. 65-84.

Deller S.C., Tsai T.S.H., Marcouiller D.W. and English D.B.K. (2001). The role of amenities and quality of life in rural economic growth, American Journal of Agricultural Economics, 83(2), pp. 352-365.

Dissart J.-C. (2006). Protection des espaces agricoles et naturels : une analyse des outils américains et français, Économie rurale, 291, pp. 6-25.

Dissart J.-C. (2005). Installations récréatives extérieures et développement économique régional : le cas des zones rurales isolées aux États-Unis, Revue d'Économie Régionale et Urbaine, 2, pp. 217-248.

Dissart J.-C., Deller S.C. (2000). Quality of life in the planning literature, Journal of Planning Literature, 15(1), pp. 135-161.

Duffy-Deno K.T. (1998). The effect of federal wilderness on county growth in the intermountain western United States, Journal of Regional Science, 38(1), pp. 109-136.

Duffy-Deno K.T. (1997a). Economic effect of endangered species preservation in the non-metropolitan West, Growth and Change, 28(3), pp. 263-288.

Duffy-Deno K.T. (1997b). The effect of state parks on the country economies of the West, Journal of Leisure Research, 29(2), pp. 201-224.

Echevin C., Gerbaux F. (1999). L'impact économique local du tourisme rural, Revue d'Économie Régionale et Urbaine, 2, pp. 295-316.

ELC (2000). Text of the European Landscape Convention in English and its explanatory report, accessed February 23, 2005, bttp://www.coe.int/t/el Cultural_Co-operation/Environment/Landscape/Reference_texts/

Convention_UnitedKingdom.asp\#Top0fPage.

English D.B.K., Bergstrom J.C. (1994). The conceptual links between recreation site development and regional economic impacts, Journal of Regional Science, 34(4), pp. 599-611.

English D.B.K., Marcouiller D.W. and Cordell H.K. (2000). Tourism dependence in rural America: Estimates and effects, Society E Natural Resources, 13, pp. 185-202. 
ECDGARD (2006). The EU rural development policy 2007-2013, factsheet accessed January 18, 2007, http://ec.europa.eulagriculture/publi/fact/rurdev2007/en_2007.pdf

Evans A.W. (1993). Interregional equilibrium: A transatlantic view, Journal of Regional Science, 33(1), pp. 89-97.

Foster R. (1977). Economic and quality of life factors in industrial location decisions, Social Indicators Research, 4, pp. 247-265.

Gauttier M. (2006). Appellations d'origine contrôlée et paysages, document INAO, ministère de l'Agriculture et de la Pêche, $76 \mathrm{p}$.

Giannias D.A. (1997). Quality of life structural analysis, Journal of Environmental Management, 49(2), pp. 157-166.

Giannias D.A. (1996). Quality of life in Southern Ontario, Canadian Journal of Regional Science, 19(2), pp. 213-223.

Glaeser E.L., Kolko J. and Saiz A. (2001). Consumer city, Journal of Economic Geography, 1, pp. 27-50.

Glaeser E.L., Scheinkman J.A. and Shleifer A. (1995) Economic growth in a crosssection of cities, Journal of Monetary Economics, 36, pp. 117-143.

Gottlieb P.D. (1994). Amenities as an economic development tool: Is there enough evidence?, Economic Development Quarterly, 8(3), pp. 270-285.

Graves P.E. (1991). Aesthetics, in: Measuring the Demand for Environmental Quality, Braden J.B., Kolstad C.D. (eds), Amsterdam, Elsevier Science, pp. 213-226.

Graves P.E. (1983). Migration with a composite amenity: The role of rents, Journal of Regional Science, 23(4), pp. 541-546.

Graves P.E. (1980). Migration and climate, Journal of Regional Science, 20(2), pp. 227-237.

Graves P.E. (1979). A life-cycle empirical analysis of migration and climate, by race, Journal of Urban Economics, 6(2), pp. 135-147.

Green G.P. (2001). Amenities and community economic development: Strategies for sustainability, Journal of Regional Analysis and Policy, 31(2), pp. 61-75.

Greenwood M.J. (1985). Human migration: Theory, models, and empirical studies, Journal of Regional Science, 25(4), pp. 521-544.

Guérin M. (2005). Évolution des objectifs et des principes d'intervention des politiques de développement rural sur le long terme, Ingénieries-EAT, numéro spécial FEADER, pp. 27-38.

Gyourko J. (1991). How accurate are quality-of-life rankings across cities?, Business Review (Federal Reserve Bank of Philadelphia), March/April, pp. 3-14.

Gyourko J., Kahn M. and Tracy J. (1999). Quality of life and environmental comparisons, in: Handbook of Regional and Urban Economics, Cheshire P., Mills E.S. (eds), Amsterdam, Elsevier Science, pp. 1413-1454. 
Gyourko J., Tracy J. (1991). The structure of local public finance and the quality of life, Journal of Political Economy, 99(4), pp. 774-806.

Hart S.L., Denison D.R. and Henderson D.A. (1989). A contingency approach to firm location: The influence of industrial sector and level of technology, Policy Studies Journal, 17(3), pp. 599-623.

Henry M.S., Barkley D.L. and Bao S. (1997). The hinterland's stake in metropolitan growth: Evidence from selected Southern regions, Journal of Regional Science, 37(3), pp. 479-501.

Hirczak M., Moalla M., Mollard A., Pecqueur B., Rambonilaza M. et Vollet D. (2005). Du panier de biens à un modèle plus général des biens complexes territorialisés : concepts, grille d'analyse et questions, Paper presented at the INRA-PSDR international symposium, Lyon, March 9-11.

Hodge I. (2000). Current policy instruments: Rationale, strengths and weaknesses, in: Valuing Rural Amenities, Paris, OECD publishing, pp. 105-125.

Johnson K.M., Fuguitt G.V. (2000). Continuity and change in rural migration patterns, 1950-1995, Rural Sociology, 65(1), pp. 27-49.

Kahley W.J. (1991). Population migration in the United States: A survey of research, Economic Review (Federal Reserve Bank of Atlanta), 76(1), pp. 12-21.

Knapp T.A., Graves P.E. (1989). On the role of amenities in models of migration and regional development, Journal of Regional Science, 29(1), pp. 71-87.

Kusmin L.D. (1994). Factors associated with the growth of local and regional economies: A review of selected empirical literature, Washington DC, Economic Research Service, US Department of Agriculture.

Lacroix A., Mollard A. et Pecqueur B. (2000). Origine et produits de qualité territoriale : du signal à l'attribut?, Revue d'Économie Régionale et Urbaine, 4, pp. 683-706.

Lippert C. (2006). Provision for valuable landscapes seen from an institutional economics' perspective, Paper presented at the $1^{\text {st }}$ workshop on landscape economics, Angers, June 9-10.

Marcouiller D.W. (1998). Environmental resources as latent primary factors of production in tourism: The case of forest-based commercial recreation, Tourism Economics, 4(2), pp. 131-145.

Marcouiller D.W., Clendenning J.G. and Kedzior R. (2002). Natural amenity-led development and rural planning, Journal of Planning Literature, 16(4), pp. 515-42.

McGranahan D.A. (1999). Natural amenities drive rural population change, Agricultural Economic Report $\mathrm{n}^{\circ} 781$, Washington DC, Economic Research Service, US Department of Agriculture.

McGregor P.G., McVittie E.P., Swales J.K. and Yin Y.P. (2000). The neoclassical economic base multiplier, Journal of Regional Science, 40(1), pp. 1-31. 
Mollard A. (2003). Multifonctionnalité de l'agriculture et territoires : des concepts aux politiques publiques, Cabiers d'économie et sociologie rurales, 66, pp. 27-54.

Mollard A. (2001). Qualité et développement territorial: une grille d'analyse théorique à partir de la rente, Économie rurale, 263, pp. 16-34.

Monod J., Castelbajac P. de (2002). L'aménagement du territoire, Paris, PUF.

Moquay P. (2005). Les modèles mobilisés dans les actions paysagères, Paper presented at the final meeting of the research program on Politiques publiques et paysages, Paris, October 20-21.

Mueser P.R., Graves P.E. (1995). Examining the role of economic opportunity and amenities in explaining population redistribution, Journal of Urban Economics, 37(2), pp. 176-200.

OECD (2001). Multifunctionality: Towards an Analytical Framework, Paris, OECD publishing.

OECD (1999). Cultivating Rural Amenities: An Economic Development Perspective, Paris, OECD publishing.

OECD (1994). The Contribution of Amenities to Rural Development, Paris, OECD publishing.

O'hUallacháin B. (1990). The location of US manufacturing: Some empirical evidence on recent geographical shifts, Environment and Planning A, 22(9), pp. 12051222.

Pearce D.W., Atkinson G. and Mourato S. (2006). Cost-Benefit Analysis and the Environment: Recent Developments, Paris, OECD publishing.

Pecqueur B. (2001). Qualité et développement territorial : l'hypothèse du panier de biens et de services territorialisés, Economie rurale, 261, pp. 37-49.

Perrier-Cornet P. (2004). L'avenir des espaces ruraux français : dynamiques et prospective des espaces ruraux français à l'horizon 2020, Futuribles, 299, pp. 77-95.

Power T.M. (2005). The supply and demand for natural amenities: An overview of theory and concepts, in: Amenities and Rural Development: Theory, Methods and Public Policy, Green G.P., Deller S.C. and Marcouiller D.W. (eds), Northampton, MA, Edward Elgar Publishing, pp. 63-77.

Power T.M. (1988). The Economic Pursuit of Quality, Armonk, New York, M.E. Sharpe.

Rambonilaza M. (2004). Évaluation de la demande de paysage: état de l'art et réflexions sur la méthode du transfert des bénéfices, Cabiers d'économie et sociologie rurales, 70, pp. 77-101.

Reichert C. von, Rudzitis G. (1992). Multinomial logistic models explaining income changes of migrants to high-amenity counties, Review of Regional Studies, 22(1), pp. 25-42.

Roback J. (1982). Wages, rents, and the quality of life, Journal of Political Economy, 90(6), pp. 1257-1277. 
Rosen S. (1979). Wage-based indexes of urban quality of life, in: Current Issues in Urban Economics, Mieszkowski P., Straszheim M. (eds), Baltimore, MD, Johns Hopkins University Press, pp. 74-104.

Schmitt B., Henry M.S., Piguet V. and Hilal M. (2006). Urban growth effects on rural population, export and service employment: Evidence from Eastern France, The Annals of Regional Science, 40(4), pp. 779-801.

Spain D. (1993). 'Been heres' and 'come heres': Negotiating conflicting community identities, Journal of the American Planning Association, 59(spring), pp. 156-171.

Stover M.E., Leven C.L. (1992). Methodological issues in the determination of the quality of life in urban areas, Urban Studies, 29(5), pp. 737-754.

Vollet D. (1998). Estimating the direct and indirect impacts of residential and recreational functions on rural areas: An application to five small areas of France, European Review of Agricultural Economics, 25, pp. 528-549.

Vollet D., Dion Y. (2001). Les apports potentiels des modèles de la base économique pour guider la décision publique : illustration à partir de quelques exemples français et québécois, Revue d'Économie Régionale et Urbaine, 2, pp. 179-186.

Vollet D., Guérin M. (2005). Effets économiques du paysage sur le développement régional: illustration à partir d'une zone rurale française (le Pays de la Météorite), Revue Canadienne des Sciences Régionales, 28(3), pp. 577-602.

Wong C. (1998). Determining factors for local economic development: The perception of practitioners in the North West and Eastern regions of the UK, Regional Studies, 32(8), pp. 707-720. 
